\section{STRUCTURE-ACTIVITY RELATIONSHIPS AMONG DERIVATIVES OF ARPHAMENINES, INHIBITORS OF AMINOPEPTIDASE B}

Sir:

Arphamenines A (1-a) and B (1-b), which were isolated from the culture filtrate of Chromobacterium violaceum BMG361-CF4, inhibit aminopeptidase B but not leucine-aminopeptidase. Arphamenines A and $\mathbf{B}$ are competitive inhibitors with a $K i$ value of $2.5 \times 10^{-9} \mathrm{M}$ and $8.4 \times 10^{-10} \mathrm{M}$ for aminopeptidase B. $^{1 \text {. }}$

The structures of arphamenines $\mathrm{A}$ and $\mathrm{B}$ are 5-amino-8-guanidino- 4 - oxo - 2 - phenylmethyloctanoic acid and 5-amino-8-guanidino-2-(4hydroxyphenylmethyl)-4-oxooctanoic acid, ${ }^{1,2)}$ respectively. Arphamenines are a new class of aminopeptidase inhibitors, with a methylene ketone $\left(-\mathrm{CO}-\mathrm{CH}_{2}-\right)$ in the place of the scissile bond $(-\mathrm{CO}-\mathrm{NH}-)$ of the substrate. In this communication, we report on some chemical modifications of arphamenines, and their structure-activity relationships. We found that some of them have high inhibitory activities for carboxypeptidases $\mathrm{A}$ and $\mathrm{B}$.

Three reactive functional groups, amino, carboxy and guanidino were modified (Scheme 1). The modification of the amino group of arphamenines was performed by acetylation (Ac), benzoylation (Bz) or benzyloxycarbonylation (Z). Acetylation of the amino group of arphamenine A with acetic anhydride in alkaline water ( $\mathrm{pH} 8.0$ ), gave $N$-acetylarphamenine A (2-a, $\left.\mathrm{C}_{18} \mathrm{H}_{28} \mathrm{~N}_{4} \mathrm{O}_{4}\right)$ in $79 \%$ yield, FDMS: $\mathrm{m} / \mathrm{z}$ $363\left(\mathrm{MH}^{+}\right)$. The amino group of arphamenine A was modified by benzoylation with benzoyl chloride in ice cold aq sodium carbonate to give $N$-benzoylarphamenine A (3-a, $\mathrm{C}_{23} \mathrm{H}_{28} \mathrm{~N}_{4} \mathrm{O}_{4}$ ) in $93 \%$ yield, FDMS: $m / z 425$ $\left(\mathrm{MH}^{+}\right)$. The amino group of arphamenine $\mathrm{A}$ was protected with benzyloxycarbonyl group by reaction with $S$-benzyloxycarbonyl-4,6-dimethyl2-mercaptopyrimidine (Kokusan Chemical Works) in dioxane-aq sodium bicarbonate, followed by column chromatography on $\mathrm{CM}$ Sephadex $\mathrm{C}-25\left(\mathrm{H}^{+}\right)$to give $\mathrm{N}$-benzyloxycarbonylarphamenine $\mathrm{A}$ (4-a) as the monohydrate $\left(\mathrm{C}_{24} \mathrm{H}_{30} \mathrm{~N}_{4} \mathrm{O}_{5} \cdot \mathrm{H}_{2} \mathrm{O}\right)$ in $72 \%$ yield, FDMS: $\mathrm{m} / \mathrm{z}$ $455\left(\mathrm{MH}^{+}\right)$.

Modification of the amino group of arphamenine B with acetyl, benzoyl or benzyloxycarbonyl group by the methods described above gave $N$-acetylarphamenine B [(2-b, $\left.\mathrm{C}_{18} \mathrm{H}_{28} \mathrm{~N}_{4} \mathrm{O}_{5}\right)$,

Scheme 1. Derivatives of arphamenines A and B.

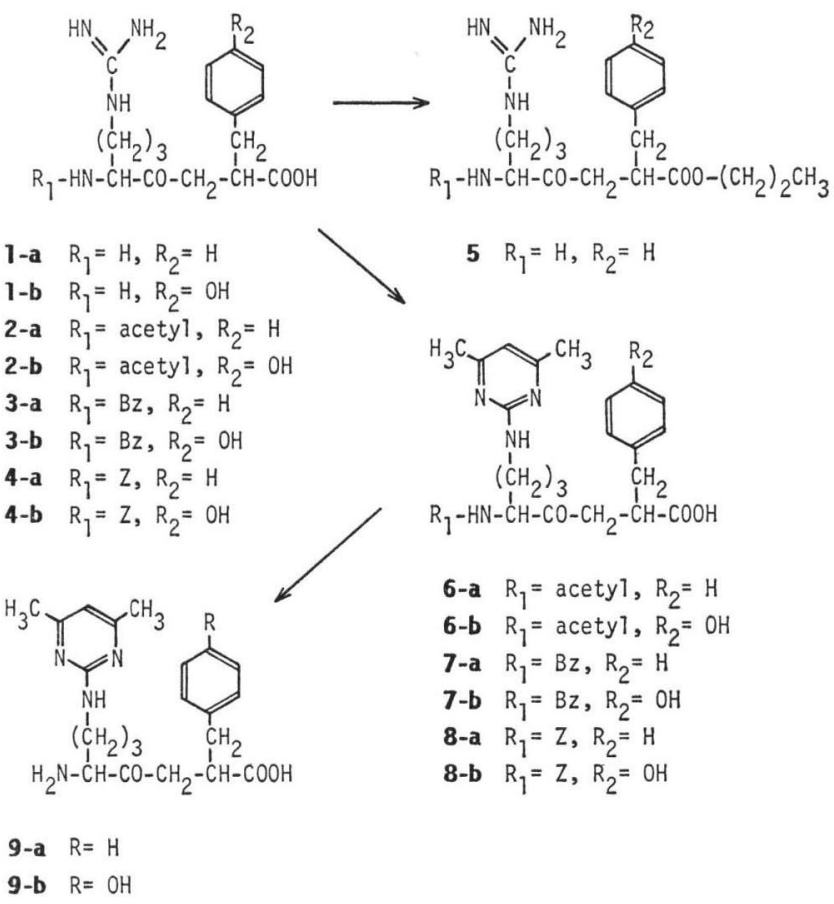


Table 1. Significant ${ }^{1} \mathrm{H}$ NMR chemical shifts of compounds 6-a, 6-b, 7-a, 7-b, 8-a and 8-b.

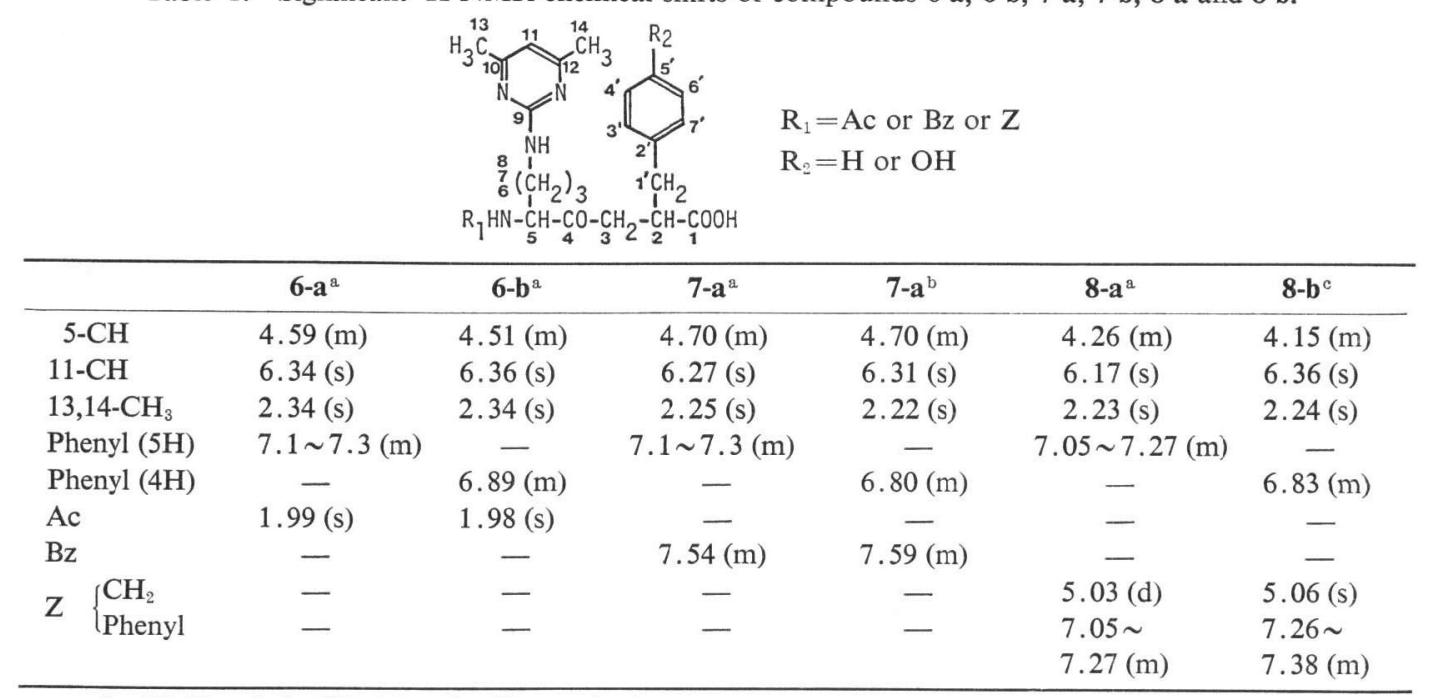

a In $\mathrm{CDCl}_{3}$, b in $\mathrm{CD}_{3} \mathrm{OD}-\mathrm{CDCl}_{3}$, c in $\mathrm{CD}_{3} \mathrm{OD}$.

Table 2. Inhibitory activity of derivatives of arphamenines.

\begin{tabular}{cccc}
\hline & \multicolumn{3}{c}{$\mathrm{IC}_{50}(\mu \mathrm{g} / \mathrm{ml})$} \\
\cline { 2 - 4 } & $\begin{array}{c}\text { Amino- } \\
\text { peptidase B }\end{array}$ & $\begin{array}{c}\text { Carboxy- } \\
\text { peptidase A }\end{array}$ & $\begin{array}{c}\text { Carboxy- } \\
\text { peptidase B }\end{array}$ \\
\hline 1-a & 0.006 & 90 & $>100$ \\
1-b & 0.002 & 5.2 & $>100$ \\
2-a & $>100$ & 2.6 & $>100$ \\
2-b & $>100$ & 3.6 & $>100$ \\
3-a & 28 & 0.10 & 80 \\
3-b & 40 & 0.32 & 26 \\
4-a & 51 & 1.1 & $>100$ \\
4-b & 2.9 & 2.4 & $>100$ \\
5 & 0.72 & $>100$ & $>100$ \\
6-a & $>100$ & 0.40 & $>100$ \\
6-b & $>100$ & 0.10 & 6.8 \\
7-a & $>100$ & 0.020 & 2.6 \\
7-b & $>100$ & 0.0088 & 0.70 \\
8-a & $>100$ & 0.064 & 90 \\
8-b & $>100$ & 0.35 & 9.0 \\
9-a & 1.5 & 40 & $>100$ \\
9-b & 0.4 & 30 & $>100$ \\
\hline
\end{tabular}

FDMS: $m / z 379\left(\mathrm{MH}^{+}\right), 80 \%$ yield], $N$-benzoylarphamenine $\mathrm{B}\left[\left(\mathbf{3}-\mathrm{b}, \mathrm{C}_{23} \mathrm{H}_{28} \mathrm{~N}_{4} \mathrm{O}_{5}\right)\right.$, FDMS: $\mathrm{m} / \mathrm{z}$ $441\left(\mathrm{MH}^{+}\right), 80 \%$ yield] and $N$-benzyloxycarbonylarphamenine $\mathrm{B}\left[\left(4-\mathrm{b}, \mathrm{C}_{24} \mathrm{H}_{30} \mathrm{~N}_{4} \mathrm{O}_{6} \cdot 1 / 2 \mathrm{H}_{2} \mathrm{O}\right)\right.$, FDMS: $m / z 471\left(\mathrm{MH}^{+}\right), 92 \%$ yield], respectively.

Esterification of the carboxyl group of arphamenine A with boron trifluoride 1-propanol reagent 15 (Tokyo Kasei Co.) gave arphamenine
A 1-propionyl ester $\left(5, \mathrm{C}_{18} \mathrm{H}_{30} \mathrm{~N}_{4} \mathrm{O}_{3} \cdot 2 \mathrm{HCl} \cdot \mathrm{H}_{2} \mathrm{O}\right)$, SIMS: $m / z 363\left(\mathrm{MH}^{+}\right)$.

The guanidino group of $N$-protected arphamenines was modified with acetylacetone in aq potassium carbonate to yield dimethylpyrimidyl derivatives. The properties of these $N$-substituted arphamenines which had been converted to dimethylpyrimidyl derivatives are as follows: $N$-Acetyldimethylpyrimidyl arphamenine A (6-a, $\mathrm{C}_{23} \mathrm{H}_{30} \mathrm{~N}_{4} \mathrm{O}_{4}$ ), EIMS: $m / z 426\left(\mathrm{M}^{+}\right), 25 \%$ yield; $\mathrm{N}$-acetyldimethylpyrimidyl arphamenine B (6-b, $\left.\mathrm{C}_{23} \mathrm{H}_{30} \mathrm{~N}_{4} \mathrm{O}_{5}\right)$, EIMS: $m / z 442\left(\mathrm{M}^{+}\right), 24 \%$ yield; $\mathrm{N}$-benzoyldimethylpyrimidyl arphamenine A (7-a, $\mathrm{C}_{28} \mathrm{H}_{32} \mathrm{~N}_{4} \mathrm{O}_{4}$ ), SIMS: $m / z 489\left(\mathrm{MH}^{+}\right), 54 \%$ yield; $N$-benzoyldimethylpyrimidyl arphamenine B (7-b, $\left.\mathrm{C}_{28} \mathrm{H}_{32} \mathrm{~N}_{4} \mathrm{O}_{5}\right)$, SIMS: $m / z 505\left(\mathrm{MH}^{+}\right)$, $23 \%$ yield; $N$-benzyloxycarbonyldimethylpyrimidyl arphamenine A (8-a, $\mathrm{C}_{28} \mathrm{H}_{34} \mathrm{~N}_{4} \mathrm{O}_{5}$. $\left.1 / 2 \mathrm{H}_{2} \mathrm{O}\right)$, SIMS: $m / z 519\left(\mathrm{MH}^{+}\right), 66 \%$ yield; $N$-benzyloxycarbonyldimethylpyrimidyl arphamenine $\mathrm{B}\left(8-\mathrm{b}, \mathrm{C}_{28} \mathrm{H}_{34} \mathrm{~N}_{4} \mathrm{O}_{6} \cdot 1 / 2 \mathrm{H}_{2} \mathrm{O}\right)$, SIMS : $m / z 544\left(\mathrm{MH}^{+}\right), 67 \%$ yield. These structures were confirmed by ${ }^{1} \mathrm{H}$ NMR spectroscopy (Table 1).

Removal of the Z-group of $\mathrm{N}$-Z-dimethylpyrimidyl arphamenines $\mathrm{A}$ and $\mathrm{B}$ with $\mathrm{HBr}$ AcOH afforded dimethylpyrimidyl arphamenines $\mathrm{A}$ and $\mathrm{B}$, respectively: Dimethylpyrimidyl arphamenine A (9-a, $\mathrm{C}_{21} \mathrm{H}_{28} \mathrm{~N}_{4} \mathrm{O}_{3} \cdot 2 \mathrm{HBr}$ ), SIMS: $m / z$ $385\left(\mathrm{MH}^{+}\right), 55.1 \%$ yield; dimethylpyrimidyl arphamenine B (9-b, $\left.\mathrm{C}_{21} \mathrm{H}_{28} \mathrm{~N}_{4} \mathrm{O}_{4} \cdot 2 \mathrm{HBr} \cdot \mathrm{H}_{2} \mathrm{O}\right)$, SIMS: $m / z 401\left(\mathrm{MH}^{+}\right), 67.7 \%$ yield. 
The structure-activity relationships were studied by comparing the inhibiting activities of these derivatives for aminopeptidase B (Table 2). The $N$-Ac-arphamenine A (2-a) did not inhibit at $100 \mu \mathrm{g} / \mathrm{ml}$, but $N$-Bz-arphamenine A (3-a) and $\mathrm{N}$-Z-arphamenine A (4-a) had very weak activity $\left(\mathrm{IC}_{50} 28\right.$ and $51 \mu \mathrm{g} / \mathrm{ml}$, respectively). These data and evidence that aminoacyl arginine shows anti-aminopeptidase $\mathrm{B}$ activity ${ }^{3}$ indicate that this enzyme has a weakly interacted lipophilic pocket near its active site.

The dimethylpyrimidyl derivative (9-a) and the 1-propionyl ester (5) of arphamenine A had weak activity $\left(\mathrm{IC}_{50} 1.5\right.$ and $0.74 \mu \mathrm{g} / \mathrm{ml}$, respectively). Arphamenine B and its derivatives are similar. These data indicate that the free amino group is essential for activity and the carboxyl and guanidino groups also are important; as in the case of bestatin the free amino and carboxyl groups are also needed for activity. ${ }^{4)}$

Many carboxypeptidases A and/or B inhibitors, such as benzylmalic acid, ${ }^{5)}$ benzylsuccinic acid ${ }^{6)}$ 2-benzyl-3-mercaptopropanoic acid ${ }^{7)}$ and 2-mercaptomethyl-5-guanopentanoic acid ${ }^{7)}$ have been reported. As arphamenine B inhibits carboxypeptidase A, we studied anticarboxypeptidases A and B activity of related derivatives of arphamenines A and B (Table 2). We found that some derivatives were potent inhibitors of carboxypeptidases A and B. 7-b showed especially strong anti-carboxypeptidases $\mathrm{A}$ and B activity $\left(K i 1.9 \times 10^{-8} \mathrm{M}\right.$ vs. carboxypeptidase A, competitive and $K i 1.1 \times 10^{-8} \mathrm{M}$ vs. carboxypeptidase B, competitive), and 8-a was a specific inhibitor of carboxypeptidase A (Ki $1.2 \times 10^{-7} \mathrm{M}$, competitive). There are some trends in the inhibiting activities of these derivatives for carboxypeptidase A. Acetyl, carbobenzoxy, benzoyl groups gave, in that order, increasing activity against carboxypeptidase A. Both $N$-protection and modification of the guanidyl group with acetylacetone gave rise to stronger activity. These observations indicate that the $N$-benzoyl group plays a significant role in the inhibition of carboxypeptidase A. This is a new class of carboxypeptidases inhibitors; the high potency does not rely on two carboxyl groups or a sulfhydryl group.
Acknowledgment

This work was partly supported by a contact from the Division of Cancer Treatment, National Cancer Institute, NO1-CM-57009, U.S.A.

Shokichi OHUCHI
HiroyuKi Suda
Hiroshi NAGANAWA
KENJI KAWAMURA
TAKAAKI AOYAGI
HAMAO UMEZAWA
Institute of Microbial Chemistry
Kamiosaki, Shinagawa-ku, Tokyo 141,
Japan

(Received August 29, 1984)

\section{References}

1) Umezawa, H.; T. Aoyagi, S. Ohuchi, A. OkuYama, H. Suda, T. Takita, M. Hamada \& T. TAKEUCHI: Arphamenine A and B, new inhibitors of aminopeptidase B, produced by bacteria. J. Antibiotics 36: 1572 1575, 1983

2) Ohuchi, S.; H. Suda, H. Naganawa, T. Takita, T. Aoyagi, H. Umezawa, H. NakaMURA \& Y. IITAKA: The structure of arphamenine A and B. J. Antibiotics 36: 1576 1580,1983

3) Yamamoto, K.; H. Suda, M. IshizuKa, T. TAKeUChI, T. AOYAGI \& H. Umezawa: Isolation of $\alpha$-aminoacyl arginines in screening of aminopeptidase B inhibitors. J. Antibiotics 33: $1597 \sim 1599,1980$

4) Nishizawa, R.; T. Saino, T. Takita, H. Suda, T. Aoyagi \& H. Umezawa: Synthesis and structure-activity relationships of bestatin analogues, inhibitors of aminopeptidase B. J. Med. Chem. 20: 510 515, 1977

5) Tanaka, T.; H. Suda, H. Naganawa, M. Hamada, T. Takeuchi, T. Aoyagi \& H. UmeZAWA: Production of $(S)$ - $\alpha$-benzylmalic acid, inhibitor of carboxypeptidase A by actinomycetes. J. Antibiotics 37: 682 684, 1984

6) Byers, L. D. \& R. Wolfenden: A potent reversible inhibitor of carboxypeptidase A. J. Biol. Chem. 247: 606 608, 1972

7) Ondetti, A. M.; M. E. Condon, J. Reid, E. F. Sabo, H.S. Cheung \& D.W. Cushman: Design of potent and specific inhibitors of carboxypeptidases A and B. Biochemistry 18: $1427 \sim 1430,1979$ 